\title{
POTENSI ANALGETIK EKSTRAK KLOROFORM DAUN TALOK (Muntingia calabura L) BESERTA PROFIL KROMATOGRAFI LAPIS TIPISNYA
}

\author{
NR. Widyaningrum ${ }^{1, *}$, Sri Saptuti. ${ }^{2}$, Radianti ${ }^{3}$, Wella Sulistiyah ${ }^{4}$ \\ ${ }^{1}$ STIKES Mamba'ul 'Ulum Surakarta \\ ${ }^{2,3,4}$ Poltekkes Bhakti Mulia Sukoharjo \\ ${ }^{1}$ thussannofx@gmail.com*
}

\begin{abstract}
Abstrak
Latar Belakang : Nyeri merupakan perasaan yang tidak nyaman akibat adanya kerusakan jaringan. Selain nyeri kerusakan jaringan akan diikuti dengan peradangan/inflamasi, kenaikan subuh dan perubahan warna area. Salah satu tanaman yang digunakan untuk mengatasi nyeri adalah kersen atau talok, dimana memiliki kandungan antara lain flavonoid, alkaloid, saponin dan tanin.

Tujuan : Untuk melakukan analisis potensi analgetik ekstrak kloroform daun talok (EKDT) beserta identifikasi profil kromatografi lapis tipisnya.

Metode : Pengujian potensi analgetik EKDT dilakukan dengan metode induksi kimia menggunakan asam asatet $1 \%$ yang disuntikkan pada mencit secara intraperitonial. Pengambilan zat aktif pada daun talok dilakukan dengan maserasi menggunakan pelarut nonpolar, yaitu kloroform. Maserat yang dihasilkan kemudian diidentifikasi kandungannya menggunakan kromatografi lapis tipis (KLT). Pengujian analgetik dilakukan dnegan membagi perlakuan menjadi 5 kelompok, yaitu kontrol positif dengan analgetik, kontrol negatif atau pelarut, EKDT dengan dosis $60 \mathrm{mg} / \mathrm{kgBB}$, EKDT dengan dosis $120 \mathrm{mg} / \mathrm{kgBB}$ dan EKDT dengan dosis $240 \mathrm{mg} / \mathrm{kgBB}$.

Hasil : Rendemen yang dihasilkan dari maserasi sebesar 6,59\%, dengan hasil skrining fitokimia menunjukkan positif mengandung alkaloid, antrakinon, saponin, polifenol dan flavonoid. Identifikasi KLT menunjukkan bercak saponin dengan hRF 91.25; alkaloid dengan hRF 93.75; fenolik dengan hRF 96.25 dan flavonoid dengan hRF 91,25. Potensi analgetik dengan pembanding asetosal berturut-turut pada dosis $60 \mathrm{mg} / \mathrm{kgBB} ; 120 \mathrm{mg} / \mathrm{kgBB}$ dan $240 \mathrm{mg} / \mathrm{kgBB}$ adalah $12,99 \% ; 17,89 \%$ dan $24,51 \%$, dimana potensi analgetik asetosal sebesar 47,55\%.

Simpulan : kandungan zat aktif EKDT sesuai dengan hasil KLT adalah saponin, alkaloid, fenolik dan flavonoid. EKDT memiliki potensi sebagai analgetik dengan metode induksi kimia pada mencit jantan.
\end{abstract}

Kata kunci : Ekstrak kloroform; talok; analgetik, KLT

\section{ANALGETIC POTENTION OF TALOK LEAVES CHLOROFORM EXTRACT (MUNTINGIA CALABURA L) INCLUDING THIN LAYER CHROMATOGRAPHY PROFILE}

Abstract

Background : Pain is an uncomfortable feeling due to tissue damage. In addition to pain tissue damage will be followed by inflammation / inflammation, dawn 
increase and discoloration of the area. One of the plants used to treat pain is kersen or talok, which contains flavonoids, alkaloids, saponins and tannins

Goal : To analyze the analgesic potential of talok leaves chloroform extract (TLCE) along with identification of the thin layer chromatographic profile

Methods : TLCE analgesic potential testing was carried out by chemical induction method using $1 \%$ acetic acid injected into mice intraperitonially. Intake of active substances on talok leaves was done by maceration using nonpolar solvents, namely chloroform. The resulting maserate was identified using a thin layer chromatography (TLC). Analgesic testing was carried out by dividing the treatment into 5 groups, namely positive control with analgesics, negative or solvent control, TLCE at a dose of $60 \mathrm{mg} / \mathrm{kgBW}, T L C E$ at a dose of $120 \mathrm{mg} / \mathrm{kgBW}$ and TLCE at a dose of $240 \mathrm{mg} / \mathrm{kgBW}$.

Results : The yield generated from maceration was $6.59 \%$, with phytochemical screening results showed positive containing alkaloids, anthraquinones, saponins, polyphenols and flavonoids. TLC identification showed saponin spots with hRF 91.25; alkaloids with hRF 93.75; phenolic with hRF 96.25 and flavonoids with hRF 91.25. Analgesic potential with successive acetosal comparison at a dose of $60 \mathrm{mg} / \mathrm{kgBW} ; 120 \mathrm{mg} / \mathrm{kgBB}$ and $240 \mathrm{mg} / \mathrm{kgBB}$ was $12.99 \% ; 17.89 \%$ and $24.51 \%$, where the analytical potential of acetosal was $47.55 \%$.

Conclussions : TLCE active substances content according to TLC results were saponins, alkaloids, phenolics and flavonoids. TLCE had the potential as an analgesic by chemical induction methods in male mice.

Keywords : analgetic; TLC; talok, chloroform

\section{PENDAHULUAN}

Pada era kemajuan zaman yang pesat ini, masyarakat cenderung sangat kritis terhadap derajat tingkat kesehatan mereka. Terlebih lagi dalam pemilihan obat yang bermanfaat. Mereka cenderung untuk lebih memilih kembali ke alam atau back to nature dalam rangka memperoleh manfaat obat yang besar dengan efek samping yang cenderung minimal. Salah satunya adalah pohon talok atau kersen.

Pohon talok (orang jawa tengah menyebutnya) atau cery atau kersen merupakan tanaman perdu yang sangat disukai anak kecil, karena memiliki buah yang rasanya manis. Pohon talok ini biasanya digunakan sebagai peneduh di pinggir jalan, karena daunnya yang rindang dan hijau. Daun talok telah lama dimanfaatkan orang Peru sebagai tanaman obat tradisional sebagai obat sakit kepala dan antiradang. Tanaman talok ini mengandung bermacam-macam flavonoida, diantaranya flavones, flavanone, flavan dan biflavan. Selain itu juga alkaloid, saponin dan tannin (Sridhar, et al., 2011).

Zakaria et al (2011) meneliti aktivitas ekstrak air, kloroform dan methanol secara invitro sebagai antiproliferatif (menghambat proliferatif atau perbanyakan sel kanker) dan antioksidan (menghambat radikal bebas). Sridhar et al (2011) menyatakan bahwa ekstrak metanol pada daun kering talok secara signifikan dapat menurunkan kadar glukosa dalam darah pada hewan uji tikus. Profil kromatografi lapis tipis pada ekstrak etanol daun talok menunjukkan bahwa 
ekstrak tersebut mengandung beberapa senyawa aktif, seperti alkaloid, polifenol, tanin, saponin dan flavonoid (Widyaningrum, et al., 2016). Fraksi semipolar ekstrak daun talok dengan menggunakan pelarut etilasetat, juga menunjukkan bahwa ekstrak etil asetat daun talok mengandung alkaloid, antrakinon, saponin dan flavonoid (Widyaningrum, et al., 2019). Baik fraksi polar dan semipolar ekstrak daun talok menunjukan hasil yang positif untuk menanggulangi nyeri pada mencit yang telah diinduksi dengan menggunakan asam asetat $1 \%$ (Widyaningrum, et al., 2016; Widyaningrum, et al., 2019). Penelitian yang lain terkait dengan peradangan, bahwasanya ekstrak etanol, etilasetat dan kloroform pada daun talok positif dapat digunakan sebagai antipiretik melalui induksi vaksin DPT pada mencit dengan rata-rata persentase daya antipiretisnya sebesar $78 \%$ 87\% (Widyaningrum, et al., 2015).

Mekanisme kerja senyawa flavonoid yang terkandung pada senyawa polar, semipolar dan nonpolar daun talok adalah menghambat kerja enzim siklooksigenase sehingga produksi prostaglandin akan menurun dan rasa nyeri akan berkurang atau bahkan hilang (Suryanto, 2012). Flavonoid juga berperan dalam penghambatan degranulasi neutrofil sehingga akan menghambat pengeluaran sitokin, radikal bebas serta enzim yang berperan dalam proses peradangan (Christiana, et al, 2012). Diduga karena hal inilah yang menyebabkan daun talok dapat digunakan sebagai analgetik.

Penelitian mengenai aktivitas daun talok sebagai analgetik juga masih jarang dilakukan sehingga memungkinkan untuk dilakukan penelitian dan pengembangan aktivitas ekstrak daun talok dari senyawa nonpolarnya. Penelitian ini juga dilengkapi dengan pengujian skrining fitokimia dan uji pendahuluan kualitatif untuk mengetahui kandungan senyawa yang terdapat pada ekstrak kloroform daun talok.

\section{Maserasi}

\section{METODE}

Pembutan ekstrak dilakukan dengan maserasi. Sebelumnya daun kersen (Muntingia calabura L) segar yang sudah tua disortasi, kemudian dicuci dan dibilas dengan aquadest guna menghilangkan kotoran. Selanjutnya daun kersen dikeringkan selama 3 hari dengan suhu rata-rata $50^{\circ} \mathrm{C}$, daun kersen kering selanjutnya diblender sampai menjadi serbuk, kemudian merendam 300 gram serbuk daun kersen dimasukkan dalam bekker glass kemudian ditambah cairan penyari kloroform sebanyak $1000 \mathrm{ml}$.

Maserasi dilakukan dengan pengadukan selama 6 jam kemudian didiamkan selama 18 jam, selanjutnya dilakukan penyaringan dengan menggunakan kain flanel. Filtrat hasil penyaringan selanjutnya diuapkan hingga diperoleh ekstrak kental.Ekstrak kental disimpan pada wadah.

\section{Skrining Fitokimia}

1) Uji Pendahuluan

Zat dipanaskan dengan air $10 \mathrm{ml}$ selama 30 menit diatas tangas air mendidih, larutan disaring. Larutan berwarna kuning sampai merah, menunjukkan adanya senyawa yang mengandung kromofor.

2) Uji Alkaloid 
Zat dipanaskan dalam tabung reaksi besar dengan $\mathrm{HCl} 1 \%(10 \mathrm{ml})$ selama 30 menit dalam penangas air mendidih. Suspensi disaring ke dalam tabung reaksi A dan B larutan sama banyak.Larutan A ditambah pereaksi Dragendroff dan larutan B ditambah pereaksi Mayer. Terbentuknya endapan dengan kedua pereaksi alkaloid tersebut menunjukkan adanya alkaloid.

3) Uji Antrakinon

Zat dididihkan selama 2 menit dengan $\mathrm{KOH} \mathrm{0,5} \mathrm{N} \mathrm{(10} \mathrm{ml)} \mathrm{dan} \mathrm{larutan}$ $\mathrm{H}_{2} \mathrm{O}_{2}(1 \mathrm{ml})$. Setelah dingin, suspensi disaring. Filtrat $(5 \mathrm{ml})$ ditambah asam asetat sampai $\mathrm{pH}$ 5, lalu ditambahkan toluene. Lapisan atas dipisahkan dan ditambahkan $\mathrm{KOH} 0,5 \mathrm{~N}$, warna merah yang terjadi pada lapisan air menunjukkan adanya antrakinon.

4) Uji Polifenol

Zat dipanaskan dengan air selama 10 menit di atas penangas air mendidih. Isaring panas-panas, setelah dingin ditambah pereaksi $\mathrm{FeCl}_{3}$. Terjadi warna hijau-biru menunjukkan adanya polifenol. Uji diulang dengan filtrat hasil pndidihan zat dengan etanol $80 \%$ selama 10 menit dalam penangas air.

5) Uji Tannin

Zat dipanaskan dengan air selama 30 menit diatas penangas air. Disaring filtrat $(5 \mathrm{ml})$ ditambah larutan $\mathrm{NaCl} 2 \%(1 \mathrm{ml})$, bila terjadi suspensi atau endapan disaring melalui kertas saring, kemudian filtrate ditambah larutan gelatin $1 \%(5 \mathrm{ml})$. terbentuk endapan menunjukkan adanya tannin atau zat samak.

6) Uji Saponin

Zat dimasukkan ke dalam tabung reaksi, tambahkan $10 \mathrm{ml}$ air panas, dinginkan dan kemudian kocok kuat-kuat selama 10 detik . terbentuknya buih yang mantap selama tidak kurang dari 10 menit, setinggi $1 \mathrm{~cm}$ sampai $10 \mathrm{~cm}$. pada penambahan 1 tetes $\mathrm{HCl} 2 \mathrm{~N}$, buih tidak hilang.

7) Uji Flavonoid

Zat dipanaskan dengan $10 \mathrm{ml}$ methanol selama 10 menit di penangas air. Disaring selagi panas, encerkan filtrate dengan $10 \mathrm{ml}$ air. Setelah dingin tambahkan $5 \mathrm{ml}$ wash benzene, kocok hati-hati, diamkan. Ambil lapisan methanol (lapisan bawah), uapkan. Residu dilarutkan dalam $5 \mathrm{ml}$ etil asetat, disaring. Uji Taubeck : Uapkan hingga kering $1 \mathrm{ml}$, basahkan residu dengan aseton, tambahkan sedikit asam borat dan asam oksalat, panaskan hati-hati di atas tangas air dan hindari pemanasan berlebihan. Campur residu yang diperoleh dngan $2 \mathrm{ml}$ eter. Amati dengan UV $366 \mathrm{~nm}$, larutan berflourecensi kuning intensif, menunjukkan adanya flavonoid.

\section{Identifikasi Zat Aktif dengan Kromatografi Lapis Tipis (KLT)}

1. Membersihkan alat dengan etanol dan dikeringkan

2. Menyiapkan fase gerak dan dijenuhkan

3. Menyiapkan fase diam (Silika gel GF 254) dan diberi tanda untuk totolan dan batas eluasi dan dioven selama 3 menit

4. Menyiapkan cuplikan standar dan sampel

5. Menotolkan cuplikan fase diam 
6. Mengeluasi cuplikan

7. Setelah batas akhir, eluasi fase diam dikeringkan

8. Diamati dibawah sinar uv $254 \mathrm{~nm}$ dan $366 \mathrm{~nm}$ warna bercak dan digambar bercak pemadamannya.

9. Diukur jarak eluasi

10. Dievaluasi dan dihitung harga Rf dan hRf.

Penetapan harga Rf bercak ekstrak etanol, ekstrak kloroform dan ekstrak etil asetat daun kersen menggunakan metode kromatografi lapis tipis dengan fase diam berupa silica gel GF 254 dan fase gerak ekstrak etanol yaitun-Butanol: Asam asetat : Air (4:1:5). Ekstrak kloroform dan etil astat menggunakan fase gerak berupa Etil asetat : Benzena (9:11). Menggunakan penyemprot : Liebermann Burcard, Vanilin Asam sulfat, $\mathrm{FeCL}_{3}, \mathrm{KOH}$ etanolis dan Uap amonia. Penampak noda dilihat dengan detektor UV $254 \mathrm{~nm}$ atau $366 \mathrm{~nm}$, noda terlihat dari pemadaman flouresensi

Perhitungan KLT

$\mathrm{Rf}=\frac{\text { Jarak titik pusat bercak dari titik awal }}{\text { Jarak garis depan dari titik depan }}$

$\mathrm{hRf}=\operatorname{Rf} \times 100$

\section{Pengujian Analgetik}

a. Pembuatan asam asetat $1 \%$

Mengambil $1 \mathrm{ml}$ asam asetat, dilarutkan dalam gelas beker dengan sedikit aquadest. Lalu masukkan dalam labu takar $100 \mathrm{ml}$ dan tambahkan aquadest ad $100 \mathrm{ml}$.

b. Pembuatan Larutan Aspirin

Aspirin sebagai kontrol positif pada uji analgetik.Dosis yang digunakan adalah $65 \mathrm{mg} / \mathrm{kgBB}$. Pembuatan larutan aspirin adalah ditimbang aspirin $26 \mathrm{mg}$ dilarutkan dengan minyak goreng ad $10 \mathrm{ml}$. volume pemberian pada mencit seberat 20 gram adalah $0,5 \mathrm{ml}$ diberikan secara oral.

c. Pengujian Analgetik

Rancangan uji mengikuti acak lengkap pola searah dengan hewan uji mencit putih jantan galur swiss dengan berat badan 20-30 gram dan umur 2,5-4 minggu sebanyak 25 ekor dibagi 5 kelompok.

1) Kelompok I adalah kontrol negatif.

Mencit diberi pelarut sediaan uji minyak goreng secara oral.

2) Kelompok II adalah kontrol positif.

Mencit diberi aspirin dosis $65 \mathrm{mg} / \mathrm{kg}$ BB secara oral.

3) Kelompok III adalah kelompok dosis $240 \mathrm{mg} / \mathrm{kg} \mathrm{BB}$

Mencit di beri ekstrak kloroform daun kersen dengan dosis 240 $\mathrm{mg} / \mathrm{kg}$ BB secara oral.

4) Kelompok IV adalah kelompok dosis $120 \mathrm{mg} / \mathrm{kg} \mathrm{BB}$.

Mencit diberi ekstrak kloroform daun kersen dengan dosis 120 $\mathrm{mg} / \mathrm{kg}$ BB secara oral.

5) Kelompok V adalah kelompok dosis $60 \mathrm{mg} / \mathrm{kg} \mathrm{BB}$.

Mencit diberi ekstrak kloroform daun kersen dengan dosis $60 \mathrm{mg} / \mathrm{kg}$ BB secara oral. 
Setelah perlakuan diatas, mencit disuntik asam asetat $1 \%$ dosis $300 \mathrm{mg} / \mathrm{kg} \mathrm{BB}$ secara intraperitoneal dengan selang waktu yang dipilih berdasarkan orientasi. Kemudian dilakukan pengamatan geliat dan dihitung jumlah geliat tiap 5 menit selama satu jam.

\section{Hasil Maserasi}

\section{HASIL DAN PEMBAHASAN}

Tabel 1. Hasil maserasi EKKT

\begin{tabular}{lcccc}
\hline $\begin{array}{c}\text { Warna } \\
\text { Ekstrak }\end{array}$ & Bau & Bentuk & $\begin{array}{c}\text { Bobot } \\
\text { Rendemen }\end{array}$ & $\begin{array}{c}\text { Persentase } \\
\text { Rendemen }\end{array}$ \\
\hline $\begin{array}{l}\text { Hitam } \\
\text { kehijauan }\end{array}$ & Khas kersen & Ekstrak kental & 6,59 gram & $6,59 \%$ \\
\hline
\end{tabular}

\section{Hasil Pengujian Kualitatif dengan Kromatografi Lapis Tipis}

Tabel 2. Hasil KLT EKDT

\begin{tabular}{|c|c|c|c|c|c|}
\hline \multirow{3}{*}{ Pereaksi } & \multicolumn{4}{|c|}{ Warna } & \multirow{3}{*}{ hRf } \\
\hline & \multicolumn{2}{|c|}{ Sebelum } & \multicolumn{2}{|r|}{ Setelah } & \\
\hline & 254 & 366 & 254 & 366 & \\
\hline $\begin{array}{l}\text { Liebermann } \\
\text { burchard }\end{array}$ & - & $\begin{array}{l}\text { Jingga, } \\
\text { hijau }\end{array}$ & hijau & Jingga, hijau & 81,$25 ; 87,5$ \\
\hline Vanillin : $\mathrm{H}_{2} \mathrm{SO}_{4}$ & jingga & jingga & Jingga & Jingga & $\begin{array}{l}72,5 ; 81,25 \\
87,5 ; 91,25\end{array}$ \\
\hline $\mathrm{FeCl}_{3}$ & Jingga & - & Jingga & - & 93,75 \\
\hline $\mathrm{KOH}$ etanolis & Kuning & Jingga & Kuning & Jingga, coklat & 81,$25 ; 93,75$ \\
\hline Uap amonia & - & Jingga & - & Kuning & 72,$5 ; 82,5$ \\
\hline
\end{tabular}

Tabel 3. Warna standar penampakan bercak berdasarkan literatur

\begin{tabular}{lll}
\hline \multicolumn{1}{c}{ Pereaksi } & \multicolumn{1}{c}{ Warna } & \multicolumn{1}{c}{ Jenis senyawa } \\
\hline Libermann burchard & Hijau, kuning, merah, biru & Saponin \\
Vanillin : asam sulfat & Berbagai warna & Alkaloid \\
$\mathrm{FeCl}_{3}$ & Berbagai warna, biru-hitam & Fenol, tannin \\
$\mathrm{KOH}$ etanolis & Merah & Antrakinon \\
$\mathrm{UV}_{220 \mathrm{~nm}-290 \mathrm{~nm}}$ & Kuning & Antrakinon \\
Uap amonia & Kuning, hijau & Flavonoid \\
\hline
\end{tabular}

Sumber: Metode fitokimia (Harborne, J.B., 2010). Petunjuk praktikum fitokimia (Maryati dan Sri wahyuni, 2010). (Markham, 2010). (Parmadi, 2010).

Pembuatan ekstrak kloroform daun talok menggunakan metode maserasi dengan hasil rendemen sebesar $6,59 \% \mathrm{~b} / \mathrm{b}$, dimana organoleptis dari maserat yang diperoleh adalah berbentuk ekstrak kental, warna hitam kehijauan, memiliki rasa pahit dan getir serta memiliki bau aromatis kersen. Pelarut yang digunakan adalah kloroform, hal ini bertujuan untuk mendapatkan zat aktif dari daun talok yang memiliki sifat nonpolar.

Selanjutnya hasil maserasi diidentifikasi menggunakan metode skrining fitokimia untuk mengetahui kandungan senyawa aktif pada ekstrak fase nonpolarnya secara kualitatif. Diperoleh hasil yang positif mengandung senyawa aktif berkromofor, dimana warna yang dihasilkan dari kuning sampai merah, 
kemudian ditambahkan $\mathrm{KOH}$ menjadi lebih intensif. Pada skrining fitokimia diperoleh hasil bahwa ekstrak kloroform daun talok (EKDT) mengandung alkaloid, antrakinon, polifenol, saponin dan flavonoid. Kemudian dilanjutkan pengujian bercak totolan menggunakan KLT lalu diamati jarak elusidasinya, sesuai dengan tabel 2.

Hasil KLT atau totolan dilengkapi dengan menyemprotkan pereagen spesifik pada bercak-bercak yang dihasilkan. Deteksi Lieberman Buchardad menunjukkan positif saponin jika muncul warna kuning, jingga dan hijau pada pengamatan UV. Positif alkaloid dapat dideteksi menggunakan vanillin asam sulfat dimana akan muncul warna hijau, biru atau jingga pada UV 254nm dan UV 366nm. Positif fenolik ditandai dengan warna jingga atau berbagai warna mulai dari hijau, merah, ungu, biru atau hitam yang berlatarbelakang kuning (Wagner, 2010)

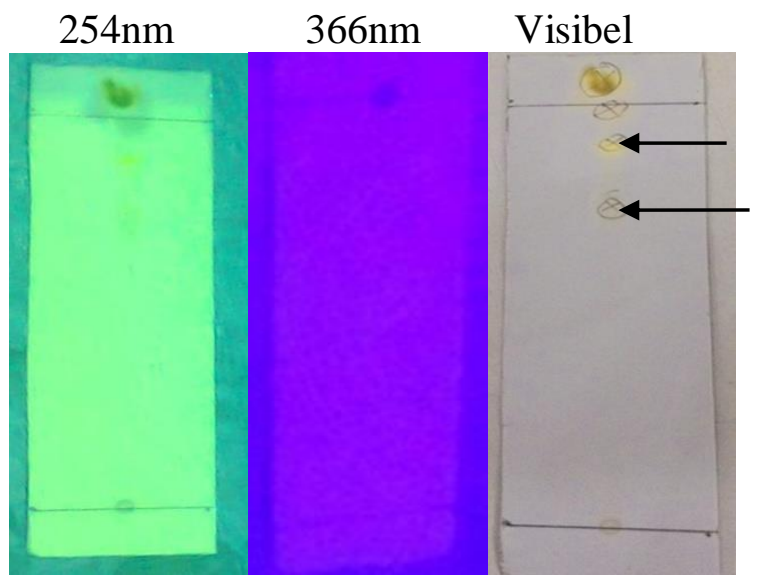

Gambar 1. EKDK pada sinar UV 254nm, 366nm dan setelah disemprot Liberman burchard

Penampakan bercak totolan pada pengamatan UV 254nm dan UV 366nm adalah sebagai berikut : pada hasil KLT EKDT positif saponin, muncul 2 bercak dengan hRf 81,25 dan 87,5; dimana jika positif saponin maka hRF standar bercak berada pada nilai 81,25 . Pereaksi semprot yang digunakan adalah Lieberman Buchardad.

Pada pereaksi semprot vanillin asam sulfat pekat positif menunjukkan alkaloid dengan timbul warna hijau, biru dan jingga. Ekstrak kloroform menampakkan warna jingga biru dengan nilai hRf 72, 5-91,25 serta warna jingga pada daerah hRf 72,5 . 


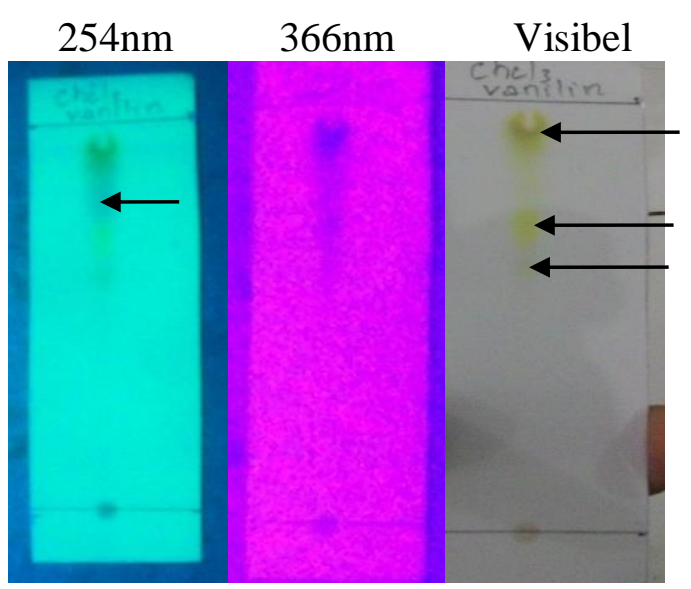

Gambar 2. EKDK pada sinar UV 254nm, 366nm dan setelah disemprot vanilin asamsulfat pk.

Pereaksi $\mathrm{FeCl}_{3}$ akan positif jika terdapat senyawa fenolik dengan timbul warna jingga atau berbagai warna. Adanya gugus fenol ditunjukkan dengan warna hijau kehitaman atau biru tua setelah ditambahkan dengan $\mathrm{FeCl}_{3}$, sehingga apabila uji dengan $\mathrm{FeCl}_{3}$ memberikan hasil positif dimungkinkan dalam sampel terdapat senyawa fenol dan dimungkinkan salah satunya adalah tannin karena tanin merupakan senyawa polifenol. Pada sinar UV pendek menghasilkan warna lembayung. Hal ini diperkuat oleh Harborne, (2010). Ekstrak kloroform menimbulkan bercak warna jingga dan hRf 93,75, menggunakan pereaksi $\mathrm{FeCl}_{3}$. Bercak yang ditimbulkan bersifat non polar karena cenderung terikat dengan fase gerak.

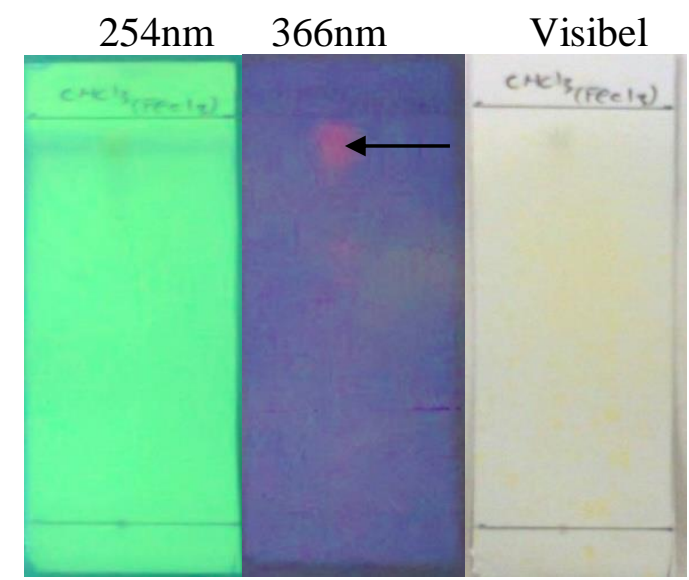

Gambar 3. EKDK pada sinar UV 254nm, 366nm dan setelah disemprot $\mathrm{FeCl}_{3}$

Deteksi kandungan antrakinon menggunakan deteksi peraksi semprot $\mathrm{KOH}$ etanolis, dimana jika positif maka akan muncul warna kuning pada sinar UV antara 220 - $290 \mathrm{~nm}$ (Harborne, 1987). Pada ekstrak kloroform menampakkan bercak berwarna kuning dilihat pada sinar UV $254 \mathrm{~nm}$, bercak tersebut diduga bercak antrakinon, dengan hRf 81,25 dan 93,75. 


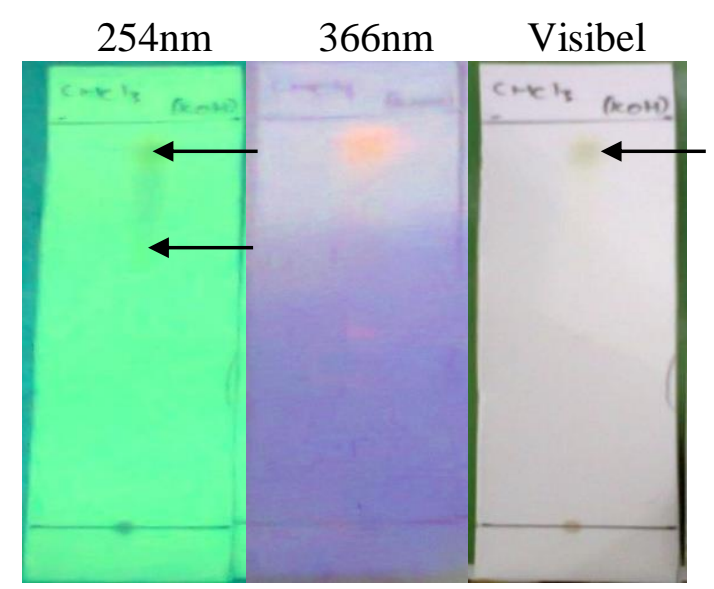

Gambar 4. EKDK pada sinar UV 254nm, 366nm dan setelah disemprot $\mathrm{KOH}$ etanolis

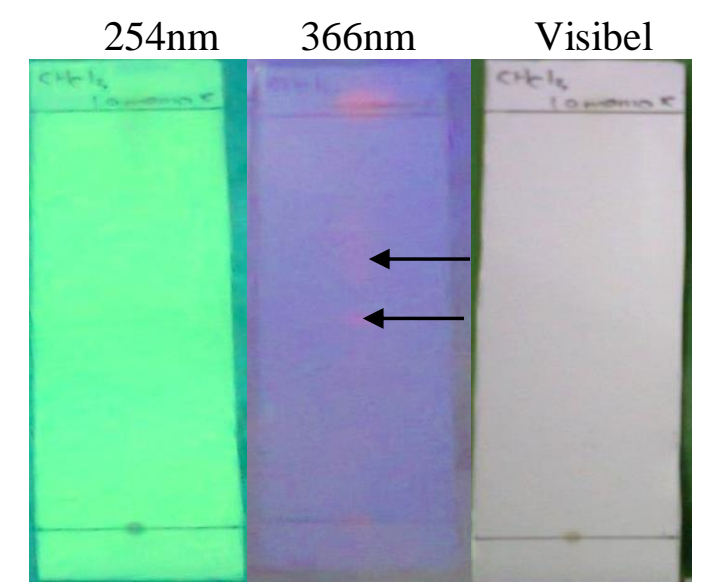

Gambar 5.EKDK pada sinar UV 254nm, 366nm dan setelah disemprot uap amonia

Pereaksi dengan uap amonia digunakan untuk mendeteksi flavonoid. Pada ekstrak kloroform menampakkan bercak berwarna kuning dengan hRf 72,5 dan 82,5.Bercak yang ditimbulkan bersifat non polar karena cenderung terikat dengan fase gerak.

Analgetik adalah bahan atau obat yang digunakan untuk menekan atau mengurangi rasa sakit atau nyeri tanpa menyebabkan hilangnya kesadaran. Uji daya analgetik daun kersen pada percobaan ini dilakukan karena melihat dari pemanfaatan tanaman obat di masyarakat masih belum dilakukan secara optimal. Belum banyak orang yang mengetahui khasiat dari tanaman kersen untuk kesehatan. Dari latar belakang tersebut maka dilakukan penelitian uji daya analgetik ekstrak kloroform daun kersen terhadap hewan uji mencit.

Mencit putih jantan digunakan pada penelitian ini sebagai hewan uji, hal ini dilakukan dengan alasan kondisi biologis yang lebih stabil dibanding mencit betina yang kondisi bologisnya dipengaruhi oleh masa siklus esterus. Selain keseragaman jenis kelamin, juga digunakan keseragaman berat badan (20-30 g) 
dan umur (35 hari). Hal ini bertujuan untuk memperkecil variabilitas biologis antara hewan uji yang digunakan, sehingga dapat memberikan respon yang relatif lebih seragam terhadap rangsangan kimia yang digunakan pada penelitian ini. Pengelompokan hewan uji dilakukan secara acak, maksudnya adalah setiap anggota dari masing-masing kelompok memiliki kesempatan yang sama untuk dijadikan sampel.

Proses untuk mengetahui potensi analgetik ekstrak kloroform daun kersen terhadap hewan uji mencit dilakukan dengan membagi hewan uji menjadi lima kelompok, yang masing-masing kelompok terdiri dari empat ekor mencit. Variasi dosis yang digunakan adalah dosis $60 \mathrm{mg} / \mathrm{kgBB}, 120 \mathrm{mg} / \mathrm{kgBB}$, dan 240 $\mathrm{mg} / \mathrm{kgBB}$, dengan alasan karena pada tanaman obat tidak ada acuan seberapa dosis mutlak yang harus diberikan pada hewan uji. Persen daya analgetik dari variasi dosis tersebut akan dibandingkan dengan persen daya analgetik kontrol positif yaitu asetosal dengan dosis $500 \mathrm{mg} / \mathrm{kgBB}$ mencit dan kontrol pelarut yaitu minyak goreng. Pengamatan dilakukan berdasarkan jumlah geliat yang merupakan reaksi nyeri yang diperlihatkan oleh hewan uji pada uji daya analgetik.

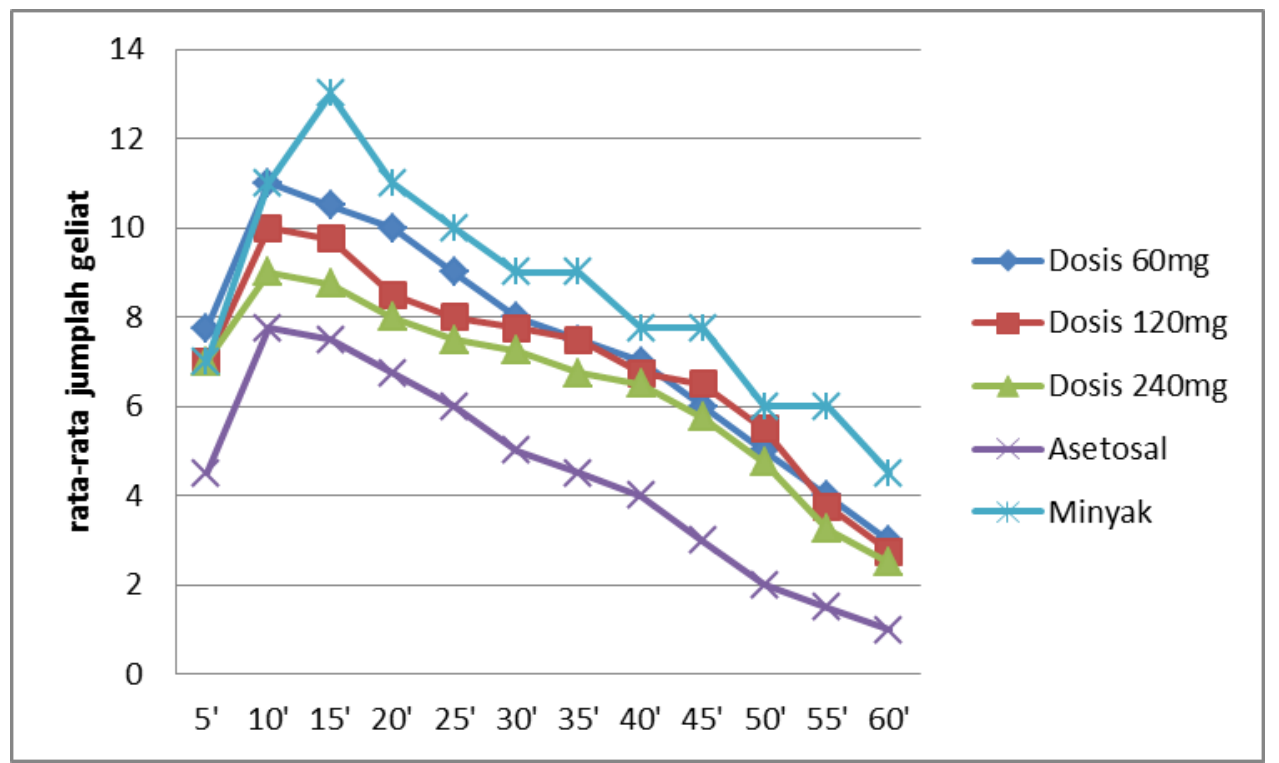

Gambar 6. Grafik Hubungan antara Waktu Percobaan dengan Geliat pada Hewan Uji Mencit.

Dari grafik diatas dapat dilihat geliat paling banyak terjadi pada kontrol pelarut (minyak goreng) dan geliat paling sedikit pada kontrol positif (asetosal) dan pada ekstrak kloroform daun kersen dosis $240 \mathrm{mg} / \mathrm{kgBB}$. Hal ini dikarenakan minyak goreng tidak memiliki efek analgetik sedangkan asetosal merupakan obat kimia yang memiliki efek analgetik yang kuat.

Penggunaan minyak goreng sebagai pelarut ekstrak kloroform sekaligus kontrol negatif karena ekstrak kloroform bersifat non polar dan tidak larut dengan air ataupun senyawa polar lainnya, sedangkan minyak goreng juga bersifat non polar. Dari sini diperkirakan ekstrak kloroform akan dapat larut pada minyak 
goreng. Daun kersen dipilih karena sebagai obat tradisional diyakini memiliki potensi analgetik.

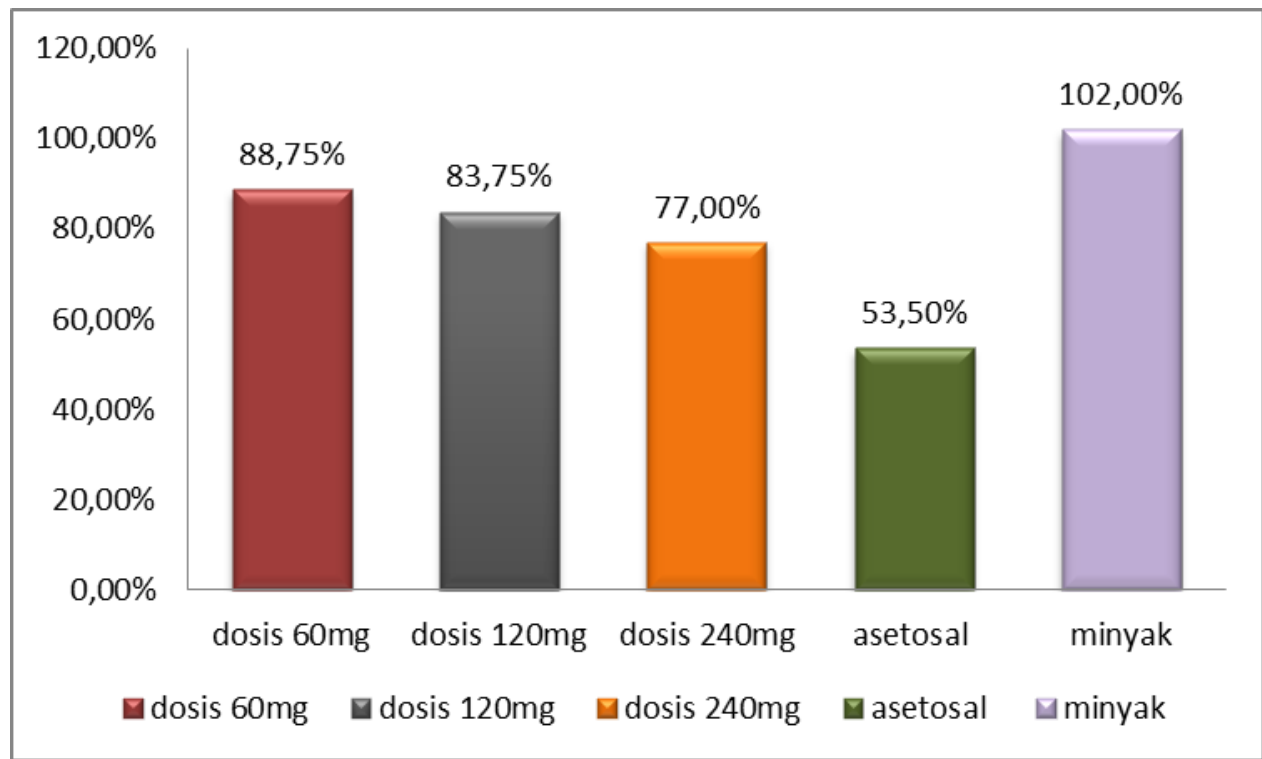

Gambar 7. Grafik Hubungan antara jenis perlakuan dengan rata-rata jumlah Geliat bentuk diagram batang.

Dari grafik diatas terlihat bahwa percobaan pada mencit dengan kontrol negatif (minyak goreng) memiliki rata-rata jumlah geliat yang paling besar dibanding dengan percobaan pada mencit dengan esktrak kloroform daun kersen dosis $60 \mathrm{mg} / \mathrm{kgBB}, 120 \mathrm{mg} / \mathrm{kgBB}, 240 \mathrm{mg} / \mathrm{kgBB}$, dan juga kontrol positif (asetosal). Pada percobaan ekstrak kloroform daun kersen dosis $60 \mathrm{mg} / \mathrm{kgBB}, 120$ $\mathrm{mg} / \mathrm{kgBB}$, dan $240 \mathrm{mg} / \mathrm{kgBB}$, rata-rata jumlah geliat secara berturut-turut adalah $88,75: 83,75: 77$. Dari hasil tersebut maka dapat dilihat bahwa pola rata-rata jumlah geliat menurun seiring dengan peningkatan dosis.

Hal ini disebabkan semakin tinggi dosis yang diberikan, maka jumlah geliat sebagai tanda nyeri juga semakin menurun. Pada grafik di atas terlihat bahwa kontrol pelarut (minyak goreng) memiliki daya geliat yang paling tinggi. Hal ini sangat relevan karena minyak goreng tidakmemiliki efek analgetik, dan ketika hewan uji merasakan nyeri maka geliat akan semakin bertambah tinggi.

Dari grafik di bawah dapat dilihat bahwa rata-rata jumlah persen daya analgetik untuk kontrol positif (asetosal) lebih besar dibandingkan dosis ekstrak kloroform daun kesen pada dosis $60 \mathrm{mg} / \mathrm{kgBB}, 120 \mathrm{mg} / \mathrm{kgBB}$ dan $240 \mathrm{mg} / \mathrm{kgBB}$. Hasil data yang diperoleh dari pengujian analgetik ini selanjutnya dianalisis secara statistik dengan uji ANOVA untuk melihat adanya perbedaan nyata efek analgetik dari kelima perlakuan yang sebelumnya harus memenuhi syarat normalitas dan homogenitas data.

Langkah pertama data diuji normalitasnya dengan menggunakan uji OneSample Kolmogorov-Smirnov Test, data dikatakan normal apabila nilai signifikasi $\mathrm{P}>$ 0,05 hal ini berarti data mempunyai varian yang sama, data terdistribusi 
normal. Uji normalitasdigunakan untuk mengukur apakah data memiliki distribusi normal sehingga dapat dipakai dalam statistik parametrik. Berdasarkan hasil uji One-Sample Kolmogorov-Smirnov Testbahwa nilai signifikasi 0,457 >0,05, maka dari data tersebut dapat diketahui data yang diperoleh terdistribusi normal.

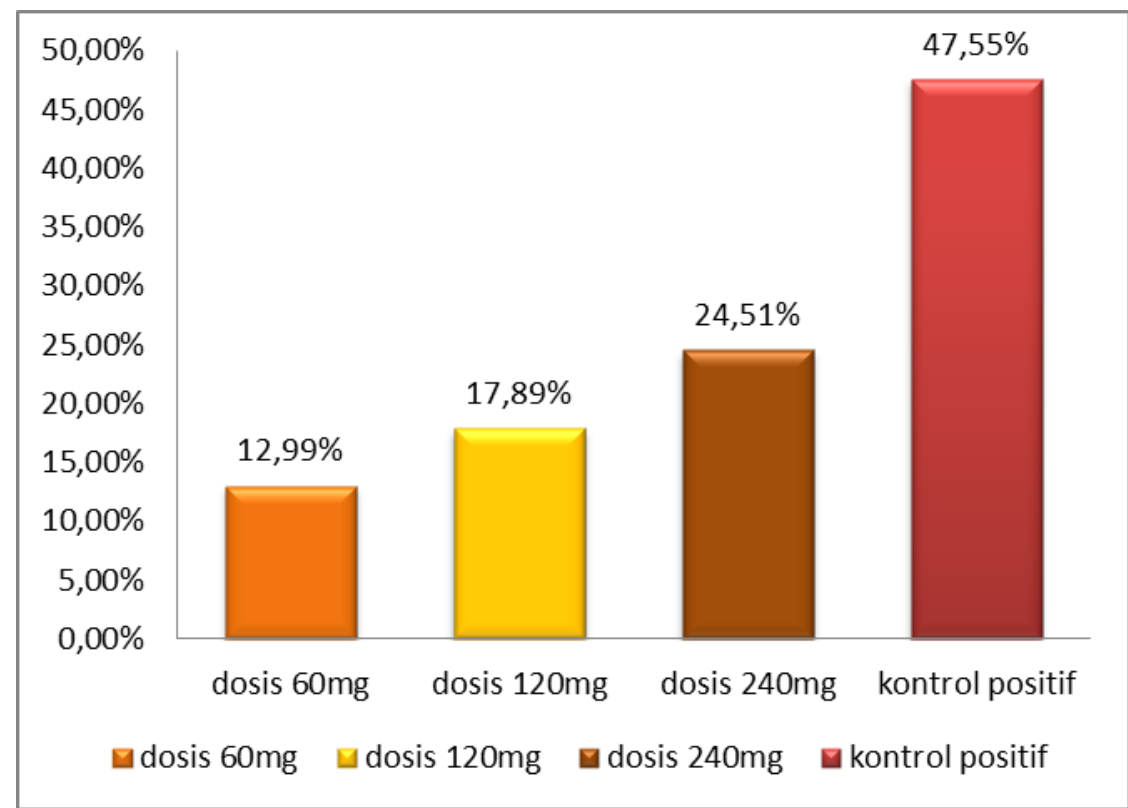

Gambar 8. Grafik Hubungan antara jenis perlakuan dengan rata-rata persendaya analgetik

Langkah selanjutnya data di analisis menggunakan Levene Test diperoleh hasil nilai signifikasi 0,605 > 0,05 maka data yang diperoleh mempunyai varian yang homogen. Kemudian dilakukan analisisoneway ANOVA, berdasarkan hasil analisisoneway ANOVA, nilai probabilitas yang tercantum pada kolom signifikasi $0,000<0,05$ maka $\mathrm{H} 0$ ditolak, ada perbedaan yang signifikan antara persen daya analgetik daun kersen. Selanjutnya dilakukan uji Post Hoc Test (LSD), dosis pemberian asetosal dengan dosis $60 \mathrm{mg} / \mathrm{kgBB}$, asetosal dengan 120 $\mathrm{mg} / \mathrm{kgBB}$, asetosal dengan $240 \mathrm{mg} / \mathrm{kgBB}$ mempunyai nilai signifikasi $0,000<$ 0,05 maka $\mathrm{H} 0$ ditolak, ada perbedaan yang signifikan antara pemberian asetosal dengan ekstrak kloroform daun kersen.

Dosis perlakuan $60 \mathrm{mg} / \mathrm{kgBB}$ dengan dosis $120 \mathrm{mg} / \mathrm{kgBB}$ diperoleh hasil signifikasi 0,134>0,05 maka H0 diterima, tidak ada perbedaan yang signifikan antara dosis $60 \mathrm{mg} / \mathrm{kgBB}$ daun kersen dengan dosis $120 \mathrm{mg} / \mathrm{kgBB}$ daun kersen. Dosis perlakuan $60 \mathrm{mg} / \mathrm{kgBB}$ dengan $240 \mathrm{mg} / \mathrm{kgBB}, 60 \mathrm{mg} / \mathrm{kgBB}$ dengan asetosal diperoleh hasil signifikasi $0,000<0,05$ maka $\mathrm{H} 0$ ditolak, ada perbedaan yang signifikan antara dosis perlakuan ekstrak kloroform daun kersen dan asetosal. Dosis $120 \mathrm{mg} / \mathrm{kgBB}$ dengan dosis $60 \mathrm{mg} / \mathrm{kgBB}$ diperoleh hasil dengan signifikasi 0,134 > 0,05 maka H0 diterima, tidak ada perbedaan yang signifikan antara dosis perlakuan $120 \mathrm{mg} / \mathrm{kgBB}$ daun kersen dan dosis $60 \mathrm{mg} / \mathrm{kgBB}$ daun kersen. Dosis $120 \mathrm{mg} / \mathrm{kgBB}$ dengan dosis $240 \mathrm{mg} / \mathrm{kgBB}$ diperoleh hasil 
signifikasi 0,051 > 0,05 maka H0 diterima, tidak ada perbedaan yang signifikan antara dosis perlakuan $120 \mathrm{mg} / \mathrm{kgBB}$ dan dosis $240 \mathrm{mg} / \mathrm{kgBB}$. Dosis perlakuan $120 \mathrm{mg} \mathrm{kgBB}$ dengan asetosal mempunyai nilai signifikasi $0,000<0,05$ maka $\mathrm{H} 0$ ditolak, ada perbedaan yang signifikan antara pemberian ekstrak kloroform daun kersen dan asetosal.

Dosis $240 \mathrm{mg} / \mathrm{kgBB}$ dengan dosis $60 \mathrm{mg} / \mathrm{kgBB}$ mempunyai nilai signifikasi $0,003<0,05$ maka H0 ditolak, ada perbedaan yang signifikan antara pemberian dosis $240 \mathrm{mg} / \mathrm{kgBB}$ dan dosis $60 \mathrm{mg} / \mathrm{kgBB}$. Dosis $240 \mathrm{mg} / \mathrm{kgBB}$ dengan 120 $\mathrm{mg} / \mathrm{kgBB}$ mempunyai nilai signifikasi 0,051 >0,05 maka $\mathrm{H} 0$ diterima, tidak ada perbedaan yang signifikan antara dosis $240 \mathrm{mg} / \mathrm{kgBB}$ dan dosis $120 \mathrm{mg} / \mathrm{kgBB}$. Dosis $240 \mathrm{mg} / \mathrm{kgBB}$ dengan asetosal mempunyai nilai signifikasi $0,000<0,05$ maka H0 ditolak, ada perbedaan yang signifikan antara pemberian ekstrak kloroform daun kersen dan asetosal.

Dari data di atas dapat disimpulkan bahwa ekstrak kloroform daun kersen memiliki potensi analgetik. Persentase daya analgetik ekstrak kloroform 24,51\% mendekati persentase kontrol positif (asetosal) sebagai pembandingnya yaitu 47,55\%. Dalam ekstrak kloroform daun kersen memiliki potensi analgetik kemungkinan dikarenakan adanya flavonoid dalam sediaan tersebut, flovonoid yang memiliki struktur kimia hampir sama dengan parasetamol yang merupakan obat kimia yang memiliki efek analgetik kuat. Mekanisme analgetik disebabkan adanya penghambatan pelepasan prostaglandin dan mediator-mediator serupa. Hal ini juga mungkin berhubungan dengan kehadiran saponin, flavonoid, dan berbagai senyawa yang terdapat di dalam ekstrak kloroform daun kersen (Muntingia calabura L). Flavonoid yang mempunyai cincin ikatan rangkap hampir sama kerjanya dengan parasetamol, sehingga memiliki daya analgetik seperti parasetamol yang merupakan obat kimia yang memiliki efek analgetik kuat. Hasil statistik pada uji analgetik menunjukkan bahwa ekstrak kloroform daun kersen memiliki perbedaan yang signifikan dengan kontrol positif (asetosal) dari nilai $\mathrm{p}<$ 0,05 .

\section{SIMPULAN}

Kandungan zat aktif EKDT sesuai dengan hasil KLT dan pengujian skrining fitokimia adalah saponin, alkaloid, fenolik dan flavonoid. Tanin tidak nampak karena hasilnya adalah negatif.

Potensi analgetik dengan pembanding asetosal berturut-turut pada dosis 60 $\mathrm{mg} / \mathrm{kgBB} ; 120 \mathrm{mg} / \mathrm{kgBB}$ dan $240 \mathrm{mg} / \mathrm{kgBB}$ adalah $12,99 \% ; 17,89 \%$ dan 24,51\%, dimana potensi analgetik asetosal sebesar 47,55\%.

\section{SARAN}

Dilakukan penelitian lanjutan untuk aktivitas antipiretik dan antiinflamasi untuk ekstrak fraksi polar, semipolar dan nonpolar. Perlu dilakukan penelitian lebih lanjutan mengenai dosis letal dan dosis toksik utuk analgetik.

Pemisahan bercak pada saat identifikasi KLT tidak sempurna, masih terdapat tumpang tindih, maka bisa dilakukan penelitian menggunakan metode yang lebih teliti seperti HPLC atau dilakukan fraksinasi senyawa nonpolar untuk senyawa yang lebih spesifik. 


\section{DAFTAR PUSTAKA}

Christiana, I., Evacuasiany, E., Hidayat, M., 2012, The Analgetic Effect of Kayu Rapat Bark Infusion (Parameria laevigata (Juss) Moldenke) On Male Mice Treated With Thermal Induction, Journal of Medical Planta, Vol. 2 No. 1

Departemen Kesehatan Republik Indonesia. 2010. Sediaan Galenik. Dirjen Jakarta : Pengawasan Obat dan Makanan.

Harborne, J.B. 2010. Metode Fitokimia II. Bandung: ITB.

Maryati dan Wahyuni, Sri. 2010. Petunjuk Praktikum Fitokimia. Surakarta: Laboratorium Fitokimia Fakultas Farmasi UMS.

Parmadi, A. 2010. Skrining Fitokimia Terhadap Tanaman Yang Mempunyai Daya Sitotoksik Terbesar Terhadap Artemia Salina (leech) Dari Beberapa Tanaman Suku Compositae. Skripsi. Fakultas Farmasi Universitas Surabaya.

Sridhar M, Thirupathi K, Chaitanya G, Kumar R, Mohan KG, 2011, Antidiabetic effect of Leaves Muntingia calabura L in Normal And Alloxan-Induced Diabetic Rats, Jurnal of Pharmacologyonline 2: 626-632, University College of Pharmaceutical Sciences; India

Wagner, H, Bladt, S., Zgainski EM. 2010. Plant Drug Analysis. Berlinheidelberg-New York: Springer Verlag Page 8, 9, 54, 55, 94, 153, 196, 226, 227.

Widyaningrum, NR., Parmadi, A., Candra, Agus, F., Budiyanto, E. 2015. Aktivitas Ekstrak Etanol, Etilasetat dan Kloroform Talok (Muntingia calabura L) sebagai Agen Penurun Panas melalui Induksi Vaksin DPT pada Mencit Ras Swiss. Prosiding. Molecules, Vol 20.

Widyaningrum, NR., Saptuti, S., Agustina, T., 2019. Identifikasi Kromatografi Lapis Tipis Dan Efektivitas Ekstrak Etilasetat Daun Talok (Muntingia calabura L) Sebagai Analgetik, Avicenna, 84 2, 84-94.

Widyaningrum, N.R., Parmadi, A., Wicaksono, W., 2016. Profil Kromatografi Lapis Tipis Ekstrak Etanol Daun Talok (Muntingia calabura L) Beserta Potensinya Sebagai Pereda Nyeri, Indonesian Journal On Medical Science, 3(1), 105-114 